\title{
Demand for Fresh Vegetables in the United States: 1970-2010
}

\author{
Cephas Naanwaab ${ }^{1,2}$ and Osei Yeboah ${ }^{1,3}$ \\ ${ }^{1}$ Department of Agribusiness, Applied Economics, and Agriscience Education, L.C. Cooper Jr. International Trade Center, \\ C.H. Moore Agricultural Research Facility, 400 N. Beech Street, Greensboro, NC 27401, USA \\ ${ }^{2}$ Department of Agribusiness, Applied Economics and Agriscience Education, Room A29, C.H. Moore Agricultural Research Facility, \\ North Carolina A and T State University, 1601 E. Market Street, Greensboro, NC 27411, USA \\ ${ }^{3}$ Department of Agribusiness, Applied Economics and Agriscience Education, Room A25, C.H. Moore Agricultural Research Facility, \\ North Carolina A and T State University, 1601 E. Market Street, Greensboro, NC 27411, USA \\ Correspondence should be addressed to Cephas Naanwaab, cbnaanwa@ncat.edu
}

Received 27 February 2012; Revised 14 September 2012; Accepted 18 September 2012

Academic Editor: Anthony N. Rezitis

Copyright ( $\odot 2012$ C. Naanwaab and O. Yeboah. This is an open access article distributed under the Creative Commons Attribution License, which permits unrestricted use, distribution, and reproduction in any medium, provided the original work is properly cited.

This paper analyzes a demand system for eight major fresh vegetables in the USA using the most recently available dataset (1970-2010). A first-differenced Linear Approximate Almost Ideal Demand System (LA-AIDS) is applied to estimate price and expenditure elasticity of demand, imposing homogeneity and symmetry restrictions. We find that not only are consumers responsive to changes in own-prices but they also respond significantly to changes in prices of other fresh vegetables that are consumed together. Conditional budget share allocation to lettuce, cabbage, and celery has declined, while the share of the consumer dollar going to tomatoes, peppers, and onions has increased over the period. Except for cabbage, all own-price elasticity estimates are negative, less than unity in absolute value, and statistically significant. About half of the 56 cross-price elasticities are negative and significant, indicating high, albeit asymmetric, complementarities among these fresh vegetables. Expenditure elasticities are positive and significant for all but one of these eight vegetables. Over the period under consideration, demand and expenditure elasticities remained fairly stable.

\section{Introduction}

The demand for fresh produce in the United States continues to increase yearly due, in large part, to consumer awareness about the linkages between diet and health. Per capita consumption of fresh vegetables increased roughly $12 \%$ between 1989 and 1999, compared to 9.9\% for all fresh fruits and vegetables [1]. Rising incomes and the changing demographic makeup of the USA population has also contributed to increased demand for fresh produce. Studies have shown that consumption of fresh fruits and vegetables is positively correlated with incomes [2]. The demand for specialty and ethnic fresh fruits and vegetables is growing, spurred by increases in Hispanic and Asian populations, who tend to have more fresh-produce-based diets than the rest of the population. According to the USA Census Bureau [3], Hispanics and Asians combined now make up about $21 \%$ of the USA population, up from $16 \%$ in the year 2000 .
Estimates show that a typical Hispanic household spent about $\$ 408$ on fresh produce in 1998 , compared to $\$ 292$ for a white household and \$217 for an African American household [2].

A number of authors have estimated the demand elasticities for fresh vegetables in the United States. Notable among them are You et al. $[4,5]$ and Henneberry et al. [6]. You, Huang, and Epperson (hereafter YHE) used data on per capita annual consumption of eight fresh vegetables from 1960 to 1993 while Henneberry, Piewthongngam, and Qiang (hereafter HPQ) used data on consumption of fourteen major vegetables from 1970 to 1992 . A considerable amount of health information has become available to consumers since these two studies were published. Consumers' attitudes to consumption of fresh vegetables may have changed as a consequence of this health awareness. The current paper contributes to the literature by empirically determining what changing patterns have occurred in the demand for fresh 
vegetables. We achieve this by using an extended dataset over the period 1970-2010 to estimate the demand for fresh vegetables in the USA.

YHE [4] found that demand for major fresh vegetables in the USA was generally price inelastic over the period 1970-1993. Their study also found that " $\mathrm{t}] \mathrm{he}$ majority of the estimated cross-price elasticities were statistically insignificant, indicating that for the eight fresh vegetables studied, generally the demand relationship were neutral." Expenditure effects were found to be highly elastic for five of these vegetables, with the exception of tomatoes, cabbages, and celery, which had insignificant or inelastic effects. YHE [5] found that demand for fresh fruits and vegetables responds significantly to changes in own-price, but not to changes in income. Thus, they concluded that income was not a significant determinant of consumer demand for fresh vegetables and fruits in the USA The current study presents evidence that these fresh vegetables exhibit more complementarities than previously thought, and that demand for these vegetables shows high responsiveness to changes in income, contrary to the findings of YHE [5].

The objective of the present paper is to analyze the effects of prices and expenditures on demand for fresh vegetables in the USA using more recent data. Estimates of price and expenditure elasticities are derived to investigate changes in demand and consumption patterns of major fresh vegetables consumed in the United States over the period of 1970 through 2010. Eight fresh vegetables, originally covered by YHE [4], including, cabbages, carrots, celery, cucumbers, lettuce, onions, peppers, and tomatoes are covered in this study. These eight account for about $80 \%$ of all fresh vegetables consumed in the USA Much like YHE [4] and HPQ [6], we apply the Linear Approximate version of the Almost Ideal Demand System (LA-AIDS) proposed by Deaton and Muellbauer [7] to estimate demand elasticities for these major fresh vegetables.

The link between diet and health has been the subject matter of intense research in the medical profession. Epidemiological studies have drawn links between the consumption of high fat diets and coronary heart diseases $[8,9]$. On the other hand, it has been established that diets rich in fiber, such as fruits and vegetables, are negatively correlated with the risk of coronary heart diseases [10]. Since the 1990s a lot of health awareness information has become available to consumers, thus, changing their attitudes to consumption of fresh vegetables. Capps and Schmitz [11] study the impact of health and nutritional awareness on food demand in the USA They found that consumers do consider health and nutritional information, usually obtained from the news media and medical personnel, in their choice of diets, particularly, with regard to consumption of food that may be high in fat and cholesterol.

As more people have access to fresh fruits and vegetables through local food systems, demand for fruits and vegetables can be expected to increase. According to the USDA [12], farmer markets have seen an exponential growth in the USA, from 1,755 in 1994 to 7,175 in 2011, an increase of more than $300 \%$. This means that more people now have access to fresh fruits and vegetables and this should reflect in increased consumption. This has also been attributed to growing interest of consumers in obtaining fresh and healthy produce.

The rest of the paper is organized as follows: Section 2 discusses the theoretical underpinnings of demand systems and Section 3 examines two-stage budgeting and weak separability. In Sections 4 and 5 we present the empirical analytical methods and data, while Section 6 discusses the results. Finally, Section 7 draws conclusions based on findings of the study.

\section{Theoretical Demand Systems}

Two approaches have generally been followed to estimate demand for any type of commodity. The first is a utility maximization approach in which consumers are assumed to choose a bundle of goods that give them maximum satisfaction given their budget. Thus, the problem facing the consumer is to solve the following constraint maximization function which specifies utility as a function of quantities consumed (direct utility) subject to the budget constraint:

$$
\begin{array}{cl}
\max & U=U(Q), \\
\text { St. } & P^{\prime} Q=Y
\end{array}
$$

Alternatively, consumers could be assumed to maximize an indirect utility function given by

$$
V(P, Y)=\max \left[U(Q): P^{\prime} Q=Y\right]
$$

where $V(P, Y)$ is the maximum attainable level of utility at given prices and income.

The solution to either (1) or (2) yields a system of demand functions

$$
\begin{aligned}
& Q^{*}=\phi(P, Y), \\
& \lambda^{*}=\lambda(P, Y),
\end{aligned}
$$

where $Q^{*}$ is the set of Marshallian or uncompensated demand functions. The above approach is known as the primal preference approach. Under duality utility theory, demand functions may also be derived from the dual problem (expenditure minimization) given by

$$
\begin{gathered}
e(P, U)=\min P Q, \\
\text { such that } U(Q) \geq U,
\end{gathered}
$$

the solution of which gives the expenditure minimizing bundle, $h(P, U)$, described as Hicksian or compensated demand functions [13].

The second approach to estimating demand is the systems approach which posits a demand system consisting of goods that belong to the same subgroup in a multistage budgeting framework. Two of the most commonly used demand systems are the Rotterdam model and the Almost Ideal Demand System (AIDS) model. According to Alston and Chalfant [14], the AIDS model has been used much more often than other demand systems such as the linear 


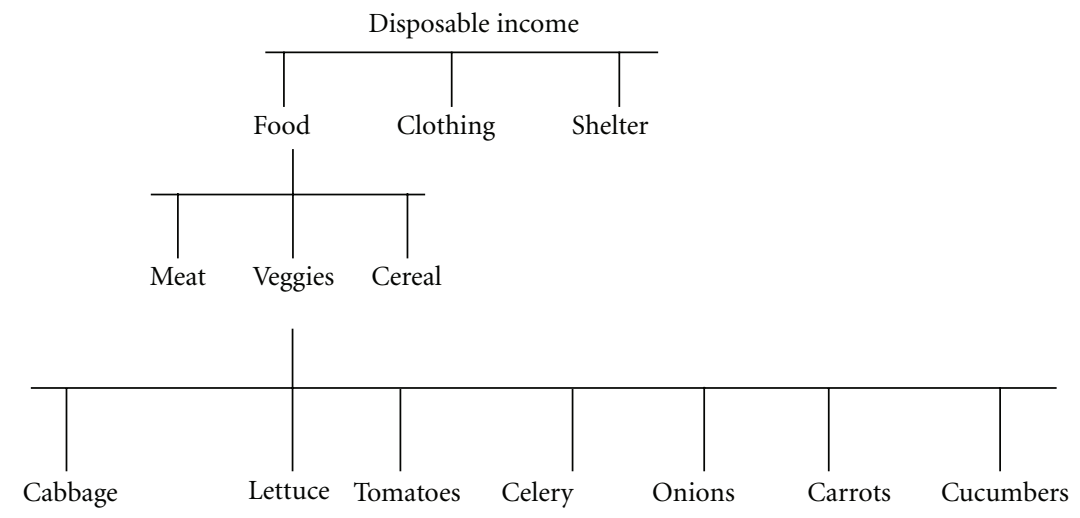

FIgURE 1: Multistage budgeting.

(or quadratic) expenditure system, or even the Rotterdam model. The popularity of the AIDS demand system has been attributed to two critical properties; first, "it is as flexible as other locally flexible functional forms (such as the Translog) and has the added advantage of being compatible with aggregation over consumers" [14]. Secondly, the AIDS system, in its Linear Approximate form (LA-AIDS), is relatively easy to estimate and permits testing of theoretical restrictions (such as homogeneity and symmetry).

The Rotterdam model was proposed by Barten [15] and Theil [16] and it is also considered as a locally flexible functional form. It has identical data requirements like the AIDS model but has been used less often, probably because of its earlier perceived restrictive nature. However, the two models do not often give the same results. For cases of incongruent outcomes using these models in demand studies, see Alston and Chalfant $[17,18]$, and Brester and Wohlgenant [19].

\section{Two-Stage Budgeting and Weak Separability}

Two-stage budgeting assumes that consumers allocate their disposable incomes to various commodities in two successive stages. Stage 1 involves allocating incomes to broad groups (e.g., food, shelter, and clothing). In stage 2 the budget of each group, such as food, is further allocated across successively disaggregated bundles of commodities (e.g., vegetables, meats, and cereal). Figure 1, adapted from Goddard [20], illustrate a multi-stage budgeting process.

Two-stage budgeting is advantageous to estimating the demand system in that at each stage one only needs information about prices and quantities on commodities within that group. For example, in Figure 1, to estimate the demand functions for the vegetables group, we need information only on prices and quantities of vegetables. According to Phlips [21], "a subset of demand equations inside a branch can be estimated using only the prices of goods and total expenditures on goods in the branch." This does not, however, imply that prices of goods outside the vegetables branch and total income are not important to the consumer's decision-making process, but rather, what it means is that prices and income in other branches (say meat and cereals) enter the vegetables branch only through their effect on the budget allocated to that branch.

A necessary and sufficient condition for two-stage budgeting is weak separability of the utility functions. Weak separability implies that commodities can be partitioned into a number of sub-groups, such that the "marginal rate of substitution between any two goods $i$ and $j$ belonging to the same group is independent of the quantities consumed of goods outside the sub-group" $[21,22]$. We assume weak separability of the fresh vegetables group. HPQ [6] found that fresh vegetables are weakly separable from fresh fruits and other food commodities.

\section{Analytical Methods}

Following YHE [4], we use the Almost Ideal Demand System (AIDS) model proposed by Deaton and Muellbauer [7] to estimate demand elasticities for fresh vegetables in the United States. The Linear Approximate version of the AIDS (LAAIDS) model is presented as follows:

$$
w_{i}=\alpha_{i}+\sum_{j=1}^{m} \gamma_{i j} \ln p_{j}+\beta_{i} \ln \left(\frac{x}{P}\right), \quad i=1,2,3, \ldots, m,
$$

where $w_{i}$ denotes the expenditure share of commodity $i, p_{j}$ is the price of the $j$ th commodity, and $x$ is the total expenditure on all $\mathrm{m}$ commodities in the subgroup. Finally, $P$ is the Stone's geometric price index, defined as:

$$
\ln P=\sum_{j=1}^{m} w_{j} \ln p_{j}
$$

The theoretical restrictions of this demand system require;

$$
\begin{gathered}
\sum_{i} \alpha_{i}=1, \quad \sum_{i} \gamma_{i j}=0, \quad \sum_{i} \beta_{i}=0, \quad \text { adding-up, } \\
\sum_{j} \gamma_{i j}=0, \quad i=1,2,3, \ldots, m, \quad \text { homogeneity, } \\
\gamma_{i j}=\gamma_{j i} \quad \text { Symmetry. }
\end{gathered}
$$

YHE [4] notes that the adding-up conditions are automatically satisfied, but homogeneity and symmetry need to 
be imposed during estimation of the system. To avoid singularity of the variance-covariance matrix in the estimation of this system, one of the equations is arbitrarily dropped. The coefficients of the dropped equation are then recovered by using the adding-up conditions.

4.1. Misspecification Tests. Misspecification testing, especially of functional form and autocorrelation, is very important in the context of systems estimation as it is in single equation estimation [23]. In the present paper, we have employed a semi-log functional form often used in the empirical literature. The LA/AIDS model follows a semi$\log$ functional form which is known to be consistent with the empirical data on household budgeting behavior [7]. Autocorrelation, however, does pose a problem in many time series studies, and the present paper is no exception. Therefore, we devote the remainder of this subsection to describe the methods and results of our autocorrelation tests. The usual test of autocorrelation most authors use is the Durbin-Watson (DW) test. However, the DW test is only good for testing equation-by-equation autocorrelation and does not take into account residual correlations across equations. For this reason, we employ a system-wide autocorrelation test in addition to the single-equation tests to test for autocorrelation in the residuals.

We first estimate the model in (5) and test for autocorrelation in per capita consumption of fresh vegetables. The tests of autocorrelation used are the DW test, Harvey single-equation LM test, and Harvey overall system LM test. The test results show that the model in levels exhibits autocorrelation both in single equations and in the system as a whole (see results of the autocorrelation tests in Table 2). The null hypothesis for this test is no autocorrelation in the residuals. Notice in Table 2 that the model in levels shows smaller $P$ values indicating rejection of the null hypotheses, while the first-differenced model has larger $P$ values indicating no autocorrelation. Thus, we find that the problem of autocorrelation is resolved by estimating the model in first differences. This confirms what earlier researchers found concerning autocorrelation in the data, that is, differencing the data can achieve stationary parameter estimates. McGuirk et al. [23] and Eales and Unnevehr [24] noted that, generally, estimating the AIDS model in differences gets rid of autocorrelation problems. Therefore, we reestimate the LA/AIDS model in levels (5) as a firstdifferenced LA-AIDS model as follows:

$$
\begin{gathered}
\Delta w_{i}=\alpha_{i}+\sum_{j=1}^{m} \gamma_{i j} \Delta \ln p_{j}+\beta_{i} \Delta \ln \left(\frac{x}{P}\right), \\
\Delta \ln P=\sum_{j=1}^{m} \Delta w_{j} \Delta \ln p_{j},
\end{gathered}
$$

where $\Delta$ is the first-difference operator (for a given series $\left.Y, \Delta Y=Y_{t}-Y_{t-1}\right)$. Significant intercepts $\left(\alpha_{i}\right)$ in $(8)$ are interpreted as time trends in expenditure shares of each commodity $i$. Upon estimating (5) or (8), demand and expenditure elasticities can be recovered as follows:

$$
\eta_{i}=\frac{\beta_{i}}{w_{i}}+1 \text { (income elasticity) }
$$

$\varepsilon_{i j}=-\delta_{i j}+\frac{\gamma_{i j}}{w_{i}}-\frac{\beta_{i} w_{j}}{w_{i}}$ (uncompensated price elasticity),

where $\delta_{i j}$ is the Kronecker delta, equal to unity for $i=j$ and zero otherwise.

As part of the misspecification tests, we have compared the static models outlined above to two dynamic models. In the first of the dynamic models, which is referred to as a general dynamic model, we included all lagged dependent variables as intercept shifters in all equations. In the second case only the lagged dependent variable of each respective equation was included as intercept shifters. In both cases, almost all the parameters of the lagged variables were statistically insignificant (results not reported). Further comparative diagnostic tests comparing the static models and dynamic models were also performed. Both the Akaike Information Criterion (AIC) and Bayesian Information Criterion (BIC) rejected the dynamic models in favor of the static models.

\section{Data and Study Period}

The data used to estimate the models are extracted from the Vegetables and Melons Yearbook jointly maintained by the USDA Economics, Statistics, and Market Information System and the Albert R. Mann Library, Cornell University. The dataset consists of US per capita annual consumption and retail prices of eight major fresh vegetables, covering the period 1970-2010. These are cabbages, carrots, celery, cucumbers, lettuce, onions, peppers, and tomatoes. Two factors guide our choice of the study period of 1970-2010. First of all, there has been a significant improvement in knowledge regarding the linkage between eating healthy foods (such as fresh vegetables) and reduced incidence of coronary heart diseases. As a consequence, we anticipate that using more recent data will accurately depict recent changes in consumption patterns of fresh vegetables. Second of all, the literature shows that there have been very few studies on demand for fresh vegetables in the USA during the period of 1970-2010. Two of the studies were conducted during an almost overlapping period: You et al. [4] covered the period 1960-1993, while Henneberry et al. [6] covered 1970-1992. There are no similar studies, to the best of our knowledge, that extends beyond the 90s into the 2000s.

Preliminary exploratory data analysis was performed to determine trends in per capita consumption over time. Figures 2(a)-2(h) plot the relationships between per capita consumption of each vegetable type and their respective retail prices. Over the period of 1970-2010, most of the fresh vegetables saw declining retail prices, but in the late 2000s prices started to creep up, especially for cabbages (Figure 2(a)), carrots (Figure 2(b)), and tomatoes (Figure $2(\mathrm{~h}))$. As prices decreased, the consumption of 


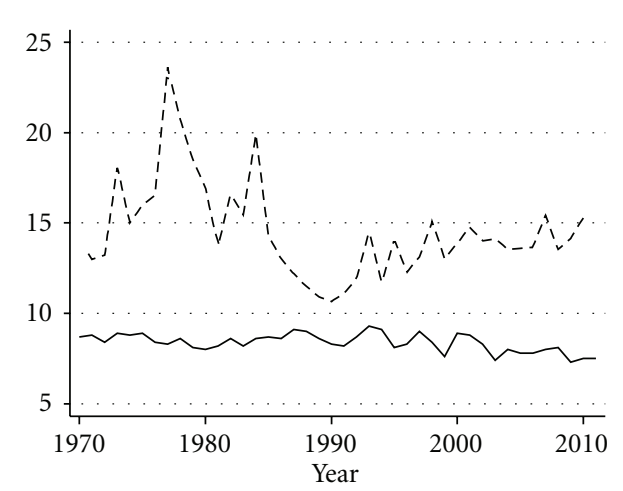

(a) US retail demand for cabbage (1970-2010)

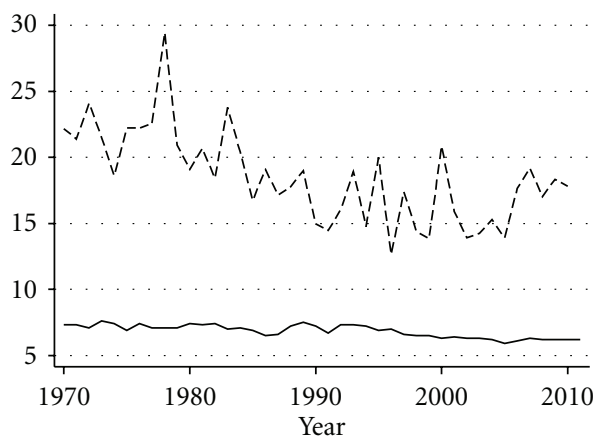

(c) US retail demand for celery (1970-2010)

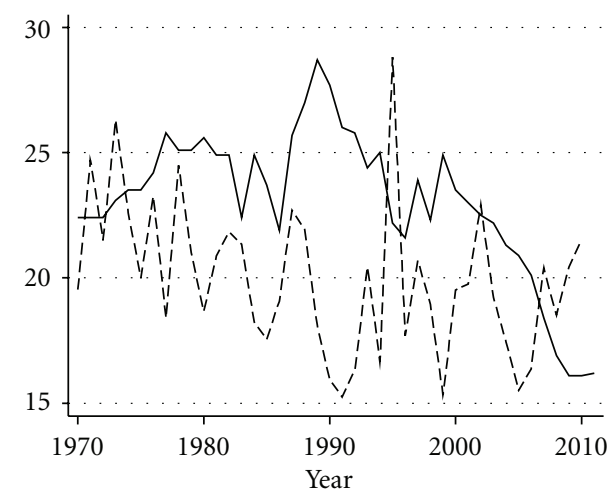

(e) US retail demand for lettuce (1970-2010)

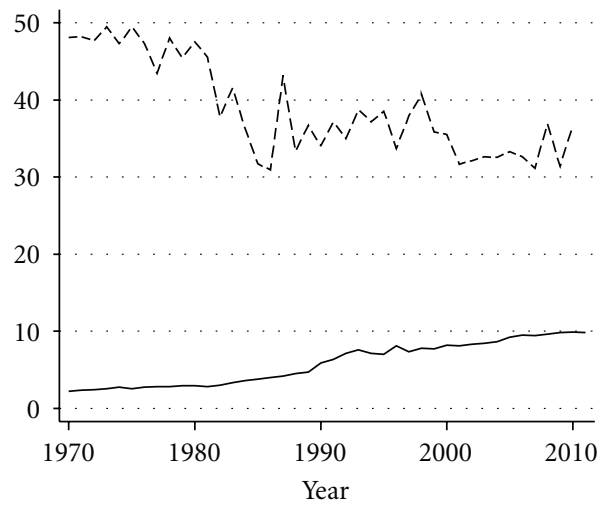

_ Per capita consumption (pounds)

(g) US retail demand for peppers (1970-2010)

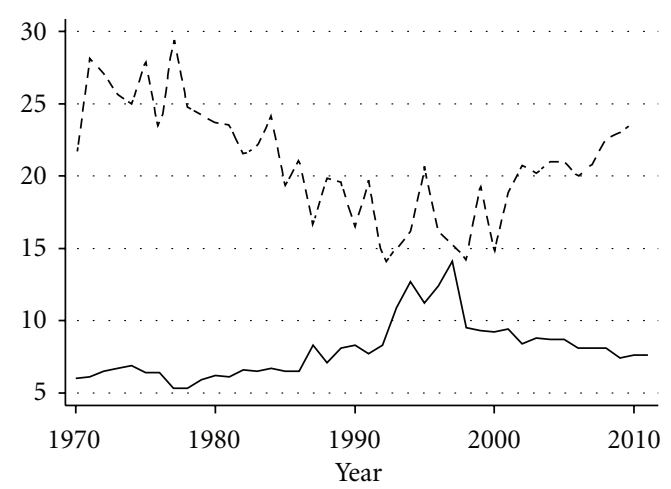

(b) US retail demand for carrots (1970-2010)

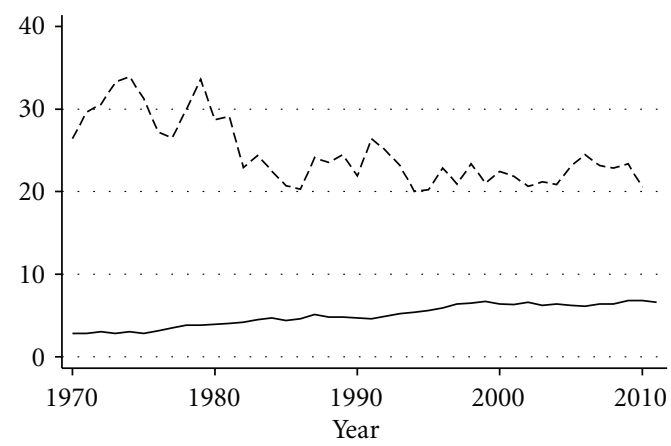

(d) US retail demand for cucumbers (1970-2010)

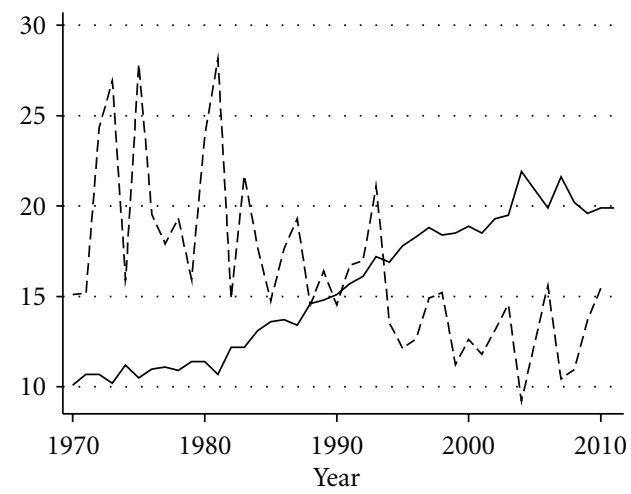

(f) US retail demand for onions (1970-2010)

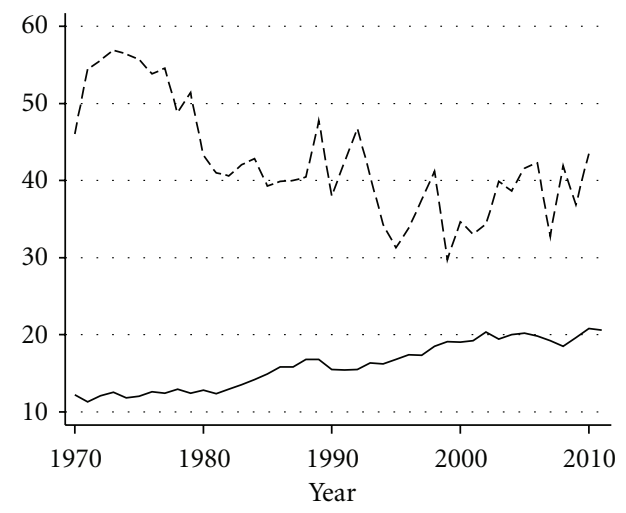

- Per capita consumption (pounds) - - - Price $(\$ / C W T)$

(h) US retail demand for tomatoes (1970-2010)

FIGURE 2: US per capita consumption of major fresh vegetables. 


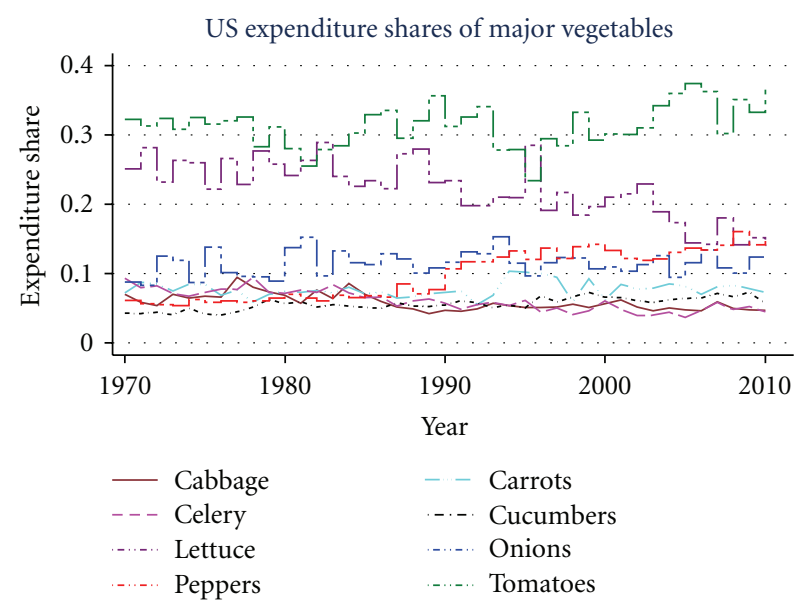

FIgURE 3: Expenditure shares.

TABLE 1: Per capita annual consumption of fresh vegetables in the USA (pounds).

\begin{tabular}{lcccccc}
\hline \multirow{2}{*}{ Commodity } & \multicolumn{7}{c}{ Period } \\
& $1970 \mathrm{~s}$ & $1980 \mathrm{~s}$ & $1990 \mathrm{~s}$ & 2000 & 2005 & 2010 \\
\hline Cabbage & 8.6 & 8.6 & 8.5 & 8.9 & 7.8 & 7.5 \\
Carrots & 6.2 & 6.8 & 10.4 & 9.2 & 8.7 & 7.6 \\
Celery & 7.2 & 7.1 & 6.9 & 6.3 & 5.9 & 6.2 \\
Cucumbers & 3.1 & 4.5 & 5.6 & 6.4 & 6.2 & 6.8 \\
Lettuce & 23.8 & 25.0 & 24.4 & 23.5 & 20.9 & 16.1 \\
Onions & 10.8 & 13.0 & 17.3 & 18.9 & 20.9 & 19.9 \\
Peppers & 2.6 & 3.7 & 7.2 & 8.2 & 9.2 & 9.9 \\
Tomatoes & 12.2 & 14.6 & 16.8 & 19.0 & 20.2 & 20.8 \\
\hline Subtotal of 8 veggies & 74.4 & 83.2 & 97.1 & 100.2 & 99.7 & 94.8 \\
All fresh veggies & 90.5 & 103.1 & 128.2 & 146.8 & 148.1 & 143.6 \\
\hline
\end{tabular}

TABLE 2: Harvey LM tests of single-equation and overall system autocorrelation.

\begin{tabular}{lcccc}
\hline \multirow{2}{*}{ Equation } & \multicolumn{2}{c}{$\begin{array}{c}\text { LA/AIDS model } \\
\text { in levels }\end{array}$} & \multicolumn{2}{c}{$\begin{array}{c}\text { First-differenced } \\
\text { LA/AIDS Model }\end{array}$} \\
& Statistic & $P$ value & Statistic & $P$ value \\
\hline Cabbages & 0.009 & 0.922 & 1.546 & 0.203 \\
Carrots & 6.230 & 0.012 & 0.258 & 0.611 \\
Celery & 2.560 & 0.109 & 0.494 & 0.482 \\
Cucumbers & 6.054 & 0.014 & 0.057 & 0.811 \\
Lettuce & 9.153 & 0.002 & 1.077 & 0.299 \\
Onions & 7.452 & 0.006 & 1.892 & 0.169 \\
Peppers & 11.150 & 0.000 & 0.102 & 0.749 \\
Tomatoes & 1.534 & 0.215 & 0.471 & 0.492 \\
\hline Overall system & 42.608 & 0.000 & 5.426 & 0.608 \\
\hline
\end{tabular}

Note: Null hypothesis tested: No autocorrelation.

most of these vegetables generally tended to increase, in line with the law of demand. Tomatoes (Figure 2(h)), onions (Figure 2(g)), cucumbers (Figure 2(d)), and peppers (Figure 2(f)) saw the most significant increases in per capita consumption. Per capita consumption of lettuce significantly decreased over the period, while cabbage, celery, and carrots stayed constant.

Using the two-stage budgeting approach, conditional expenditure shares were computed for each of these vegetables. Figure 3 presents plots of these conditional expenditure shares over the period 1970-2010. Most of the expenditure shares have stayed constant while a few registered modest increases or declines over the period. In particular, the expenditure shares of tomatoes and peppers increased, while lettuce, cabbage, and celery saw a decline in share of budget allocation, and the remaining vegetables had stable budget share allocations. The conditional budget shares indicate that a dollar allocated to these eight vegetables in 1970 were broken down as follows: (cabbage: $\not 7$, carrots: $\not 8$, celery: $\not 8$, cucumbers: $\not 5$, lettuce: $\not 25$, onions: $\phi 10$, pepper: $\not 5$, and tomatoes: $\not 32)$. In 2010, the share allocation of the consumer dollar was (cabbage: $\not 5$, carrots: $\phi 7$, celery: $\not 4$, cucumbers: $\not 6$, lettuce: $\not 14$, onions: $\not 12$, pepper: $\not 15$, and tomatoes: $\notin 37)$.

\section{Results and Discussion}

Table 1 presents a decadal comparison of per-capita consumption of each vegetable type from 1970s to the 2000s. Consumption of cucumbers, onions, peppers and tomatoes has been increasing through the decades. The demand for cabbages, carrots, celery, and lettuce has held steady or decreased over the decades. Overall, the total consumption of these eight fresh vegetables has been steadily increasing from 1970 until 2000. The decline in consumption of these eight fresh vegetables from 2000 to 2010 could be attributed to the uptick in prices during that period (Figures $2(\mathrm{a})-2(\mathrm{~h})$ ). On the whole, however, total consumption of all fresh vegetables has been increasing over the entire period of 1970-2010. This may be a reflection of health consciousness on the part of consumers.

In order to derive demand elasticity estimates for these fresh vegetables, we fitted the data using the Linearly Approximated AIDS model. The LA-AIDS model in levels, (5), was estimated to determine the presence or otherwise of serial correlation in the random error terms (see Table 4). We tested for homogeneity and symmetry restrictions in all equations, results of which are presented in Table 3. Testing each of these restrictions at the $5 \%$ level, we find that homogeneity and symmetry cannot be rejected (Table 3 ). Adding-up is automatically satisfied, thus, there was no need to impose it. To avoid singularity of the variancecovariance matrix, we dropped the tomatoes equation from the analysis. The coefficients in the tomatoes equation were then recovered using the adding-up conditions. It was found, using Durbin-Watson Statistics, that all the equations exhibited low to moderate autocorrelation (Table 4). The DW tests corroborate those of the Harvey LM test presented in Table 2. The coefficient of autocorrelation (rho) along with corresponding Durbin-Watson Statistics range from $0.013(\mathrm{DW}=1.87)$ for the cabbage equation to a high of 0.465 ( $\mathrm{DW}=0.95)$ for the pepper equation (Table 4$)$. Therefore, the first-differenced LA-AIDS model, (8), which 
TABLE 3: Tests of homogeneity and symmetry restrictions.

\begin{tabular}{|c|c|c|}
\hline Null Hypothesis & Asymptotic $t$-value & $P$ value \\
\hline Homogeneity does not hold in cabbage equation & 1.80 & 0.071 \\
\hline Homogeneity does not hold in carrots equation & -1.28 & 0.205 \\
\hline Homogeneity does not hold in celery equation & -1.30 & 0.199 \\
\hline Homogeneity does not hold in cucumbers equation & 0.27 & 0.790 \\
\hline Homogeneity does not hold in lettuce equation & -0.63 & 0.535 \\
\hline Homogeneity does not hold in onions equation & -0.98 & 0.336 \\
\hline Symmetry between cabbage and carrots & -0.88 & 0.378 \\
\hline Symmetry between celery and cabbage & 2.08 & 0.035 \\
\hline Symmetry between cucumbers and cabbage & 1.25 & 0.219 \\
\hline Symmetry between lettuce and cabbage & -1.35 & 0.128 \\
\hline Symmetry between onions and cabbage & 0.24 & 0.818 \\
\hline Symmetry between pepper and cabbage & -0.19 & 0.856 \\
\hline Symmetry between celery can carrots & -1.82 & 0.068 \\
\hline Symmetry between cucumbers and carrots & -1.60 & 0.111 \\
\hline Symmetry between lettuce and carrots & 0.32 & 0.756 \\
\hline Symmetry between onions and carrots & -0.91 & 0.372 \\
\hline Symmetry between pepper and carrots & -2.16 & 0.028 \\
\hline Symmetry between cucumbers and celery & 2.51 & 0.009 \\
\hline Symmetry between lettuce and celery & 0.55 & 0.593 \\
\hline Symmetry between onions and celery & 1.79 & 0.073 \\
\hline Symmetry between pepper and celery & -1.64 & 0.102 \\
\hline Symmetry between lettuce and cucumbers & 1.95 & 0.050 \\
\hline Symmetry between onions and cucumbers & -0.78 & 0.447 \\
\hline Symmetry between pepper and cucumbers & -0.78 & 0.447 \\
\hline Symmetry between onions and lettuce & -1.28 & 0.204 \\
\hline Symmetry between pepper and lettuce & -1.06 & 0.299 \\
\hline Symmetry between pepper and onions & 1.39 & 0.168 \\
\hline
\end{tabular}

TABLE 4: Parameter estimates for eight fresh vegetables using LA/AIDS model (in levels).

\begin{tabular}{|c|c|c|c|c|c|c|c|c|c|c|}
\hline \multirow{2}{*}{ Elasticity of } & \multicolumn{10}{|c|}{ Price coefficients } \\
\hline & Cabbages & Carrots & Celery & Cucumbers & Lettuce & Onions & Peppers & Tomatoes & Income coeff. & Rho [DW] \\
\hline Cabbages & $\begin{array}{l}0.0616 \\
(12.79)\end{array}$ & $\begin{array}{c}-0.0218 \\
(-4.01)\end{array}$ & $\begin{array}{c}0.0014 \\
(0.24)\end{array}$ & $\begin{array}{c}-0.0090 \\
(-1.05)\end{array}$ & $\begin{array}{c}-0.0074 \\
(-1.33)\end{array}$ & $\begin{array}{c}-0.0025 \\
(-0.73)\end{array}$ & $\begin{array}{c}-0.0062 \\
(-0.72)\end{array}$ & $\begin{array}{c}-0.0199 \\
(-2.72)\end{array}$ & $\begin{array}{l}-0.089 \\
(-7.01)\end{array}$ & 0.013 [1.87] \\
\hline Carrots & $\begin{array}{c}-0.0117 \\
(-1.61)\end{array}$ & $\begin{array}{l}0.0468 \\
(3.82)\end{array}$ & $\begin{array}{c}-0.0199 \\
(-1.51)\end{array}$ & $\begin{array}{c}-0.0212 \\
(-1.10)\end{array}$ & $\begin{array}{l}-0.0009 \\
(-0.08)\end{array}$ & $\begin{array}{c}-0.0095 \\
(-1.21)\end{array}$ & $\begin{array}{c}0.0569 \\
(2.91)\end{array}$ & $\begin{array}{c}-0.0030 \\
(-1.83)\end{array}$ & $\begin{array}{l}0.0247 \\
(0.86)\end{array}$ & $0.367[1.19]$ \\
\hline Celery & $\begin{array}{c}0.0009 \\
(0.21)\end{array}$ & $\begin{array}{l}-0.0167 \\
(-3.29)\end{array}$ & $\begin{array}{c}0.0542 \\
(9.89)\end{array}$ & $\begin{array}{c}-0.0051 \\
(-0.63)\end{array}$ & $\begin{array}{c}-0.0073 \\
(-1.41)\end{array}$ & $\begin{array}{c}-0.0014 \\
(-0.44)\end{array}$ & $\begin{array}{c}0.0036 \\
(0.45)\end{array}$ & $\begin{array}{c}-0.0310 \\
(-4.54)\end{array}$ & $\begin{array}{c}-0.1054 \\
(-8.89)\end{array}$ & $0.242[1.48]$ \\
\hline Cucumbers & $\begin{array}{l}0.0062 \\
(1.14)\end{array}$ & $\begin{array}{l}0.0040 \\
(0.66)\end{array}$ & $\begin{array}{c}-0.0005 \\
(-0.07)\end{array}$ & $\begin{array}{l}0.0502 \\
(5.15)\end{array}$ & $\begin{array}{l}-0.0156 \\
(-2.47)\end{array}$ & $\begin{array}{c}-0.0063 \\
(-1.60)\end{array}$ & $\begin{array}{c}-0.0135 \\
(-1.38)\end{array}$ & $\begin{array}{c}-0.0324 \\
(-3.90)\end{array}$ & $\begin{array}{c}0.0434 \\
(3.01)\end{array}$ & $0.357[1.20]$ \\
\hline Lettuce & $\begin{array}{l}-0.0035 \\
(-0.11)\end{array}$ & $\begin{array}{c}-0.0934 \\
(-2.52)\end{array}$ & $\begin{array}{c}-0.0182 \\
(-0.46)\end{array}$ & $\begin{array}{l}0.0027 \\
(0.05)\end{array}$ & $\begin{array}{c}0.1563 \\
(4.14)\end{array}$ & $\begin{array}{c}0.0106 \\
(0.45)\end{array}$ & $\begin{array}{c}0.0093 \\
(0.16)\end{array}$ & $\begin{array}{c}-0.1207 \\
(-2.43)\end{array}$ & $\begin{array}{c}-0.3636 \\
(-4.22)\end{array}$ & $0.424[1.00]$ \\
\hline Onions & $\begin{array}{l}-0.0098 \\
(-1.16)\end{array}$ & $\begin{array}{l}0.0120 \\
(1.26)\end{array}$ & $\begin{array}{c}-0.0034 \\
(-0.33)\end{array}$ & $\begin{array}{c}0.0018 \\
(0.12)\end{array}$ & $\begin{array}{c}-0.0283 \\
(-2.90)\end{array}$ & $\begin{array}{c}0.0824 \\
(13.57)\end{array}$ & $\begin{array}{c}-0.0248 \\
(-1.65)\end{array}$ & $\begin{array}{l}-0.0204 \\
(-1.59)\end{array}$ & $\begin{array}{c}0.0856 \\
(3.86)\end{array}$ & $0.411[1.13]$ \\
\hline Peppers & $\begin{array}{c}-0.0115 \\
(-0.58)\end{array}$ & $\begin{array}{l}0.0318 \\
(1.42)\end{array}$ & $\begin{array}{c}-0.0035 \\
(0.15)\end{array}$ & $\begin{array}{c}0.0198 \\
(0.56)\end{array}$ & $\begin{array}{c}-0.0429 \\
(-1.87)\end{array}$ & $\begin{array}{c}-0.0358 \\
(-2.51)\end{array}$ & $\begin{array}{l}0.0671 \\
(1.90)\end{array}$ & $\begin{array}{l}0.0169 \\
(0.56)\end{array}$ & $\begin{array}{c}0.3090 \\
(5.91)\end{array}$ & $0.465[0.95]$ \\
\hline Tomatoes & $\begin{array}{c}-0.0265 \\
(-1.46)\end{array}$ & $\begin{array}{c}0.0372 \\
(1.81)\end{array}$ & $\begin{array}{l}-0.0101 \\
(-0.46)\end{array}$ & $\begin{array}{c}-0.0392 \\
(-1.23)\end{array}$ & $\begin{array}{l}-0.0538 \\
(-2.57)\end{array}$ & $\begin{array}{l}-0.0373 \\
(-2.86)\end{array}$ & $\begin{array}{l}-0.0917 \\
(-2.84)\end{array}$ & $\begin{array}{l}0.2376 \\
(8.62) \\
\end{array}$ & $\begin{array}{l}0.0953 \\
(1.99) \\
\end{array}$ & $0.174[1.42]$ \\
\hline
\end{tabular}

Note: Numbers in parentheses are $t$-ratios, Rho: first-order autocorrelation coefficient, Durbin-Watson statistics in square brackets. 
corrects for autocorrelation was estimated using Zellner's [22] Seemingly Unrelated Regression (SUR).

As in other studies we estimated the Rotterdam model using our dataset for the purpose of selecting the model that fits the data best. However, the Rotterdam model did not produce satisfactory results. That is to say that all the own-price elasticities turned up positive and statistically insignificant. Based on these unexpected elasticity signs, we rejected the Rotterdam model in favor of the AIDS model. Alston and Chalfant [18] show, using data on Canadian meat demand, that the AIDS and Rotterdam models do not always yield similar results. Thus, we present demand elasticity estimates based on the first-differenced LA-AIDS model. The parameter estimates of the first-differenced LA-AIDS model with homogeneity and symmetry restrictions imposed are presented in Table 5. All the own-price coefficient estimates are statistically significant; cross-price effects are mostly negative and significant, while only two expenditure coefficients are significant.

Using the elasticity formulas in (9) and (10) we derived the uncompensated price and expenditure elasticities at the mean expenditure share of each commodity. Table 6 presents these uncompensated demand elasticities. With the exception of cabbage, all own-price elasticities are negative and statistically significant at the $5 \%$ level. Moreover, the estimates show that, with the exception of cabbage, all the vegetables have inelastic demand over the period 19702010. The estimated own-price elasticities are carrots: -0.29 , celery: -0.10 , cucumbers: -0.99 , lettuce: -0.37 , onions: -0.20 , peppers: -0.16 , and tomatoes: -0.44 . These estimates, although pretty close, do not exactly equal those of YHE (carrots: -0.40 , celery: -0.12 , cucumbers: -0.30 , lettuce: -0.34 , onions: -0.29 , peppers: -0.13 , and tomatoes: -0.36 ) and HPQ (carrots: -1.65 , onions: -0.29 , tomatoes: -0.23 , cucumbers: -0.73 , and green peppers: 0.84 ) who used data over 1960-1993. Except that of peppers, all expenditure elasticities are statistically significant at the 5\% level. HPQ [6] found that most of these vegetables are income elastic or "luxuries," however, our results show that only two of these vegetables are considered "luxury" commodities by consumers, based on income elasticity greater 1 (carrots: 2.35, lettuce: 1.39). The others are "normal" goods with income elasticities less than 1 (cabbages: 0.93 , celery: 0.75 , cucumbers: 0.84 , onions: 0.77 , and tomatoes: 0.69 ).

All the cross-price elasticities that are statistically significant are negative, indicating complementarities in the consumption of these fresh vegetables. Close to half of the 56 cross-price elasticities are significantly different from zero, which is in contrast to YHE [4] where the majority of cross-price elasticities were not significant. For example, the cross-price elasticities show that there is a high degree of complementarity between carrots and lettuce $(-0.50)$, carrots and tomatoes $(-0.59)$, lettuce and tomatoes $(-0.38)$, and cucumbers and tomatoes $(-0.47)$. Our results further show that these cross-price elasticities are not symmetric. So for example, the change in demand for lettuce with respect to a change in price of tomatoes is -0.38 , while the change in demand for tomatoes given a change in price of lettuce is only -0.04 . In other words, while lettuce is a strong complement with tomatoes, one cannot say that tomatoes are a strong complement with lettuce. Put differently, if the price of tomatoes goes down by $1 \%$, then consumers increase their demand for lettuce by $0.38 \%$. However, if the price of lettuce goes down by $1 \%$, consumers do not significantly change their demand for tomatoes. The same can be said about the relationship between carrots and lettuce, carrots and tomatoes, and cucumbers and tomatoes.

With changing consumer attitudes towards their choice of diets, we thought it was worthy of consideration to estimate these demand and expenditure elasticities over time to observe what changes there has been with regards to consumption of fresh vegetables. Thus, Table 7 presents the demand elasticities estimated at mean expenditure shares of different years. Similarly, Table 8 presents the expenditure elasticities over time. It can be inferred from Table 7 that the demand elasticities for most of these vegetables have remained fairly stable over the period under consideration. Table 8 shows that the expenditure elasticities have also generally remained constant throughout the period.

The effect of consumers' income on demand for fresh vegetables is implicitly accounted for in the LA/AIDS model. AIDS models typically include an expenditure (income) effect. Our estimated expenditure elasticities show that consumer demand for fresh vegetables does respond to changes in aggregate expenditures (income effect). Generally, almost all the eight vegetable types have elastic demand with respect to expenditure. This corroborates the assertion that higher income people do patronize fresh produce more than the lower income people [2].

6.1. Limitations of the Study. The major limitation of the present study is an inability to perform the analyses at a more disaggregated level such as state, county, or even the individual-level. This is primarily due to lack of disaggregated data. While data on per capita consumption of fresh vegetables is readily available at the national level, the same cannot be said about the state or county levels. Future research may explore ways of generating micro data to analyze the demand for fresh vegetables. Our inability to directly control for health information in this study is a serious limitation that we propose to undertake in future research: a health information index that captures consumers' awareness of the importance of consuming fresh vegetables should be incorporated in the analysis. This will help to explain the changing patterns in per capita vegetables consumption resulting from a heightened awareness of the linkage between diet and health.

\section{Conclusion}

Consumers have become increasingly more conscious of what they eat, as information on diet-related illnesses, such as coronary heart diseases, obesity, hypertension, and strokes, has filtered through the news media. The impact of this heightened awareness of diet-health relationship can be expected to lead to increases in demand for "healthy" foods such as fruits and vegetables and decreases in the 
TABle 5: Parameter estimates for eight fresh vegetables using a first-differenced LA/AIDS model with homogeneity and symmetry restrictions.

\begin{tabular}{|c|c|c|c|c|c|c|c|c|c|c|}
\hline \multirow{2}{*}{ Elasticity of } & \multicolumn{10}{|c|}{ Price coefficients } \\
\hline & Cabbages & Carrots & Celery & Cucumbers & Lettuce & Onions & Peppers & Tomatoes & Income coeff. & $\mathrm{R}-\mathrm{Sq}$ \\
\hline Cabbages & $\begin{array}{l}0.0643 \\
(17.21)\end{array}$ & $\begin{array}{c}-0.0128 \\
(-4.66)\end{array}$ & $\begin{array}{l}-0.0020 \\
(-0.86)\end{array}$ & $\begin{array}{l}-0.0028 \\
(-1.02)\end{array}$ & $\begin{array}{l}-0.0161 \\
(-5.17)\end{array}$ & $\begin{array}{c}-0.0074 \\
(-3.75)\end{array}$ & $\begin{array}{c}-0.0064 \\
(-1.64)\end{array}$ & $\begin{array}{l}-0.0167 \\
(-3.75)\end{array}$ & $\begin{array}{l}-0.0035 \\
(-0.20)\end{array}$ & 0.92 \\
\hline Carrots & $\begin{array}{c}-0.0128 \\
(-4.66)\end{array}$ & $\begin{array}{c}0.0633 \\
(11.55)\end{array}$ & $\begin{array}{c}-0.0066 \\
(-2.89)\end{array}$ & $\begin{array}{l}-0.0040 \\
(-1.66)\end{array}$ & $\begin{array}{l}-0.0157 \\
(-3.12)\end{array}$ & $\begin{array}{c}-0.0051 \\
(-1.76)\end{array}$ & $\begin{array}{l}-0.0061 \\
(-1.46)\end{array}$ & $\begin{array}{l}-0.0129 \\
(-1.95)\end{array}$ & $\begin{array}{l}0.1049 \\
(3.29)\end{array}$ & 0.82 \\
\hline Celery & $\begin{array}{c}-0.0020 \\
(-0.86)\end{array}$ & $\begin{array}{c}-0.0066 \\
(-2.89)\end{array}$ & $\begin{array}{c}0.0538 \\
(18.32)\end{array}$ & $\begin{array}{c}-0.0009 \\
(-0.36)\end{array}$ & $\begin{array}{l}-0.0103 \\
(-3.51)\end{array}$ & $\begin{array}{c}-0.0046 \\
(-2.50)\end{array}$ & $\begin{array}{l}-0.0092 \\
(-2.66)\end{array}$ & $\begin{array}{l}-0.0202 \\
(-5.54)\end{array}$ & $\begin{array}{c}-0.0149 \\
(-1.06)\end{array}$ & 0.93 \\
\hline Cucumbers & $\begin{array}{c}-0.0028 \\
(-1.02)\end{array}$ & $\begin{array}{c}-0.0040 \\
(-1.66)\end{array}$ & $\begin{array}{l}-0.0009 \\
(-0.36)\end{array}$ & $\begin{array}{c}0.0574 \\
(12.95)\end{array}$ & $\begin{array}{l}-0.0135 \\
(-4.75)\end{array}$ & $\begin{array}{c}-0.0076 \\
(-4.24)\end{array}$ & $\begin{array}{c}0.0005 \\
(0.12)\end{array}$ & $\begin{array}{l}-0.0291 \\
(-7.23)\end{array}$ & $\begin{array}{l}-0.0085 \\
(-0.61)\end{array}$ & 0.87 \\
\hline Lettuce & $\begin{array}{l}-0.0161 \\
(-5.17)\end{array}$ & $\begin{array}{l}-0.0157 \\
(-3.12)\end{array}$ & $\begin{array}{c}-0.0103 \\
(-3.51)\end{array}$ & $\begin{array}{l}-0.0135 \\
(-4.75)\end{array}$ & $\begin{array}{c}0.1586 \\
(16.93)\end{array}$ & $\begin{array}{c}-0.0216 \\
(-5.54)\end{array}$ & $\begin{array}{l}-0.0246 \\
(-4.65)\end{array}$ & $\begin{array}{c}-0.0568 \\
(-7.09)\end{array}$ & $\begin{array}{c}0.0848 \\
(1.64)\end{array}$ & 0.92 \\
\hline Onions & $\begin{array}{c}-0.0074 \\
(-3.75)\end{array}$ & $\begin{array}{c}-0.0051 \\
(-1.76)\end{array}$ & $\begin{array}{c}-0.0046 \\
(-2.50)\end{array}$ & $\begin{array}{c}-0.0076 \\
(-4.24)\end{array}$ & $\begin{array}{c}-0.0216 \\
(-5.54)\end{array}$ & $\begin{array}{l}0.0876 \\
(29.23)\end{array}$ & $\begin{array}{l}-0.0126 \\
(-3.83)\end{array}$ & $\begin{array}{l}-0.0288 \\
(-6.12)\end{array}$ & $\begin{array}{c}-0.0256 \\
(-1.04)\end{array}$ & 0.96 \\
\hline Peppers & $\begin{array}{c}-0.0064 \\
(-1.64)\end{array}$ & $\begin{array}{c}-0.0061 \\
(-1.46)\end{array}$ & $\begin{array}{c}-0.0092 \\
(-2.66)\end{array}$ & $\begin{array}{l}0.0005 \\
(0.12)\end{array}$ & $\begin{array}{c}-0.0246 \\
(-4.65)\end{array}$ & $\begin{array}{c}-0.0126 \\
(-3.83)\end{array}$ & $\begin{array}{c}0.0789 \\
(9.47)\end{array}$ & $\begin{array}{l}-0.0205 \\
(-2.86)\end{array}$ & $\begin{array}{c}-0.0390 \\
(-1.40)\end{array}$ & 0.77 \\
\hline Tomatoes & $\begin{array}{l}-0.0167 \\
(-3.75)\end{array}$ & $\begin{array}{l}-0.0129 \\
(-1.95)\end{array}$ & $\begin{array}{l}-0.0202 \\
(-5.54)\end{array}$ & $\begin{array}{l}-0.0291 \\
(-7.23)\end{array}$ & $\begin{array}{c}-0.0568 \\
(-7.09)\end{array}$ & $\begin{array}{c}-0.0288 \\
(-6.12)\end{array}$ & $\begin{array}{l}-0.0205 \\
(-2.86)\end{array}$ & $\begin{array}{c}0.1117 \\
(14.76)\end{array}$ & $\begin{array}{l}-0.0982 \\
(-4.03)\end{array}$ & 0.91 \\
\hline
\end{tabular}

Note: Numbers in parentheses are $t$-ratios.

TABle 6: Demand elasticity estimates (at sample mean shares) computed from first-differenced LA/AIDS model with homogeneity and symmetry restrictions.

\begin{tabular}{|c|c|c|c|c|c|c|c|c|c|}
\hline \multirow{2}{*}{ Elasticity of } & \multicolumn{9}{|c|}{ Price of } \\
\hline & Cabbages & Carrots & Celery & Cucumbers & Lettuce & Onions & Peppers & Tomatoes & Expenditure elasticity \\
\hline Cabbages & $\begin{array}{l}0.107 \\
(1.10)\end{array}$ & $\begin{array}{l}-0.219 \\
(-2.44)\end{array}$ & $\begin{array}{l}-0.030 \\
(-0.11)\end{array}$ & $\begin{array}{l}-0.048 \\
(-0.86)\end{array}$ & $\begin{array}{l}-0.261 \\
(-3.78)\end{array}$ & $\begin{array}{l}-0.113 \\
(-3.42)\end{array}$ & $\begin{array}{l}-0.097 \\
(-1.17)\end{array}$ & $\begin{array}{l}-0.271 \\
(-2.44)\end{array}$ & $\begin{array}{l}0.931 \\
(4.37)\end{array}$ \\
\hline Carrots & $\begin{array}{l}-0.245 \\
(-4.02)\end{array}$ & $\begin{array}{l}-0.297 \\
(-3.56)\end{array}$ & $\begin{array}{l}-0.172 \\
(-2.13)\end{array}$ & $\begin{array}{l}-0.127 \\
(-1.65)\end{array}$ & $\begin{array}{l}-0.503 \\
(-4.69)\end{array}$ & $\begin{array}{l}-0.218 \\
(-4.38)\end{array}$ & $\begin{array}{l}0.209 \\
(0.74)\end{array}$ & $\begin{array}{l}-0.589 \\
(-5.05)\end{array}$ & $\begin{array}{l}2.346 \\
(6.19)\end{array}$ \\
\hline Celery & $\begin{array}{l}-0.019 \\
(-0.65)\end{array}$ & $\begin{array}{l}-0.096 \\
(-3.04)\end{array}$ & $\begin{array}{l}-0.100 \\
(-2.56)\end{array}$ & $\begin{array}{l}-0.001 \\
(-0.55)\end{array}$ & $\begin{array}{l}-0.110 \\
(-1.16)\end{array}$ & $\begin{array}{l}-0.054 \\
(-0.55)\end{array}$ & $\begin{array}{l}-0.123 \\
(-1.64)\end{array}$ & $\begin{array}{l}-0.251 \\
(-3.77)\end{array}$ & $\begin{array}{l}0.754 \\
(2.92)\end{array}$ \\
\hline Cucumbers & $\begin{array}{l}0.044 \\
(0.07)\end{array}$ & $\begin{array}{l}-0.059 \\
(-1.67)\end{array}$ & $\begin{array}{l}-0.006 \\
(-1.76)\end{array}$ & $\begin{array}{c}-0.995 \\
(-20.41)\end{array}$ & $\begin{array}{l}-0.214 \\
(-2.59)\end{array}$ & $\begin{array}{l}-0.125 \\
(-2.29)\end{array}$ & $\begin{array}{l}-0.025 \\
(-0.16)\end{array}$ & $\begin{array}{l}-0.467 \\
(-6.17)\end{array}$ & $\begin{array}{l}0.839 \\
(3.28)\end{array}$ \\
\hline Lettuce & $\begin{array}{l}-0.095 \\
(-2.48)\end{array}$ & $\begin{array}{l}-0.102 \\
(-0.88)\end{array}$ & $\begin{array}{l}-0.069 \\
(-2.65)\end{array}$ & $\begin{array}{l}-0.085 \\
(-1.07)\end{array}$ & $\begin{array}{l}-0.366 \\
(-5.63)\end{array}$ & $\begin{array}{l}-0.143 \\
(-5.28)\end{array}$ & $\begin{array}{l}-0.151 \\
(-0.24)\end{array}$ & $\begin{array}{l}-0.379 \\
(-5.16)\end{array}$ & $\begin{array}{l}1.385 \\
(6.90)\end{array}$ \\
\hline Onions & $\begin{array}{l}-0.048 \\
(-0.70)\end{array}$ & $\begin{array}{l}-0.026 \\
(-0.30)\end{array}$ & $\begin{array}{l}-0.030 \\
(-0.69)\end{array}$ & $\begin{array}{l}-0.057 \\
(-0.40)\end{array}$ & $\begin{array}{l}-0.143 \\
(-1.45)\end{array}$ & $\begin{array}{l}-0.202 \\
(-4.15)\end{array}$ & $\begin{array}{l}-0.092 \\
(-2.21)\end{array}$ & $\begin{array}{l}-0.183 \\
(-2.94)\end{array}$ & $\begin{array}{l}0.772 \\
(2.94)\end{array}$ \\
\hline Peppers & $\begin{array}{l}-0.038 \\
(-1.69)\end{array}$ & $\begin{array}{l}-0.030 \\
(-2.92)\end{array}$ & $\begin{array}{l}-0.068 \\
(-1.54)\end{array}$ & $\begin{array}{l}0.027 \\
(1.23)\end{array}$ & $\begin{array}{l}-0.167 \\
(-0.73)\end{array}$ & $\begin{array}{l}-0.087 \\
(-0.17)\end{array}$ & $\begin{array}{l}-0.155 \\
(-2.47)\end{array}$ & $\begin{array}{l}-0.089 \\
(-1.16)\end{array}$ & $\begin{array}{l}0.602 \\
(0.66)\end{array}$ \\
\hline Tomatoes & $\begin{array}{l}-0.016 \\
(-0.11)\end{array}$ & $\begin{array}{c}0.009 \\
(-1.22)\end{array}$ & $\begin{array}{l}-0.025 \\
(-0.43)\end{array}$ & $\begin{array}{l}-0.057 \\
(-1.59)\end{array}$ & $\begin{array}{l}-0.039 \\
(-1.21)\end{array}$ & $\begin{array}{l}-0.019 \\
(-0.40)\end{array}$ & $\begin{array}{l}-0.003 \\
(-2.63)\end{array}$ & $\begin{array}{l}-0.443 \\
(-5.07)\end{array}$ & $\begin{array}{l}0.687 \\
(3.27)\end{array}$ \\
\hline
\end{tabular}

Asymptotic $t$-ratios in parentheses.

consumption of "unhealthy" foods. With this in mind, this study sought to investigate trends in per capita consumption of fresh vegetables in the United States, using recent data on eight fresh vegetables which make up $80 \%$ of the vegetable portion of most households. This is not the first of its kind, but the current study utilizes a more recent dataset, 19702010, which previous studies, notably YHE [4] and HPQ [6], did not have access to. We adopted a systems approach to demand analysis, in which the LA-AIDS model was estimated by Zellner's seemingly unrelated regression method. 
TABLE 7: Demand elasticities estimated at the expenditure shares of different years.

\begin{tabular}{|c|c|c|c|c|c|c|}
\hline \multirow{2}{*}{ Commodity } & \multicolumn{6}{|c|}{ Period } \\
\hline & $1970 \mathrm{~s}$ & $1980 \mathrm{~s}$ & $1990 \mathrm{~s}$ & 2000 & 2005 & 2010 \\
\hline & \multicolumn{6}{|c|}{ Uncompensated own-price elasticity } \\
\hline Cabbage & $-0.077(-1.67)$ & $0.033(0.07)$ & $0.256(2.93)$ & $0.134(1.35)$ & $0.358(4.00)$ & $0.382(4.27)$ \\
\hline Carrots & $-0.277(-3.20)$ & $-0.230(-2.47)$ & $-0.339(-4.29)$ & $-0.094(-0.63)$ & $-0.331(-4.11)$ & $-0.242(-2.65)$ \\
\hline Celery & $-0.298(-8.24)$ & $-0.195(-4.94)$ & $0.063(0.57)$ & $-0.089(-2.22)$ & $0.492(5.93)$ & $0.221(3.05)$ \\
\hline Cucumbers & $0.253(2.86)$ & $0.068(1.08)$ & $-0.030(-0.03)$ & $-0.126(-1.59)$ & $-0.098(-1.14)$ & $0.012(0.41)$ \\
\hline Lettuce & $-0.459(-7.06)$ & $-0.449(-7.01)$ & $-0.336(-5.14)$ & $-0.329(-5.03)$ & $0.016(-0.60)$ & $-0.047(-0.27)$ \\
\hline Onions & $-0.112(-1.44)$ & $-0.244(-5.39)$ & $-0.245(-5.39)$ & $-0.170(-3.22)$ & $-0.212(-4.33)$ & $-0.268(-6.07)$ \\
\hline Peppers & $0.377(1.51)$ & $0.178(0.47)$ & $-0.332(-5.16)$ & $-0.369(-5.90)$ & $-0.382(-6.17)$ & $-0.424(-7.09)$ \\
\hline Tomatoes & $-0.547(-5.11)$ & $-0.534(-4.50)$ & $-0.526(-4.32)$ & $-0.532(-4.54)$ & $-0.604(-7.34)$ & $-0.597(-7.08)$ \\
\hline
\end{tabular}

Asymptotic $t$-ratios in parentheses.

TABLE 8: Elasticities estimated at the expenditure shares of different years.

\begin{tabular}{|c|c|c|c|c|c|c|}
\hline \multirow{2}{*}{ Commodity } & \multicolumn{6}{|c|}{ Period } \\
\hline & $1970 \mathrm{~s}$ & $1980 \mathrm{~s}$ & $1990 \mathrm{~s}$ & 2000 & 2005 & 2010 \\
\hline & \multicolumn{6}{|c|}{ Expenditure Elasticity } \\
\hline Cabbage & $0.943(5.05)$ & $0.936(4.62)$ & $0.922(3.94)$ & $0.929(4.31)$ & $0.915(3.69)$ & $0.914(3.63)$ \\
\hline Carrots & $2.381(6.13)$ & $2.459(6.01)$ & $2.276(6.31)$ & $2.684(5.71)$ & $2.290(6.28)$ & $2.438(6.04)$ \\
\hline Celery & $0.809(4.18)$ & $0.780(3.44)$ & $0.709(2.26)$ & $0.751(2.85)$ & $0.590(1.15)$ & $0.665(1.74)$ \\
\hline Cucumbers & $0.804(2.53)$ & $0.833(3.13)$ & $0.848(3.51)$ & $0.863(4.04)$ & $0.859(3.89)$ & $0.842(3.36)$ \\
\hline Lettuce & $1.335(7.43)$ & $1.340(7.42)$ & $1.400(6.73)$ & $1.404(6.70)$ & $1.589(5.48)$ & $1.605(5.40)$ \\
\hline Onions & $0.745(2.40)$ & $0.784(3.21)$ & $0.785(3.21)$ & $0.762(2.75)$ & $0.775(2.98)$ & $0.792(3.37)$ \\
\hline Peppers & $-1.581(-1.78)$ & $-0.159(-0.40)$ & $0.689(1.57)$ & $0.708(1.93)$ & $0.714(2.08)$ & $0.735(2.44)$ \\
\hline Tomatoes & $0.689(3.29)$ & $0.677(3.03)$ & $0.670(2.61)$ & $0.675(3.05)$ & $0.738(4.42)$ & $0.733(4.27)$ \\
\hline
\end{tabular}

Asymptotic $t$-ratios in parentheses.

The results show that the demand for these vegetables is generally inelastic, both with respect to own-prices as well as cross-prices. The results show significant complementary, but asymmetric, relationship between these fresh vegetables than previously found by YHE [4], which suggests that most of these fresh vegetables tend to be consumed together. Expenditure elasticities are positive and statistically significant. Over time, the demand and expenditure elasticities have remained stable during the period 1970-2010.

\section{Acknowledgments}

The paper greatly benefitted from SAS programming codes provided by Kilungu Nzaku, Center for Business and Economic Research, University of Alabama. The authors also thank two anonymous reviewers for providing useful comments that greatly improved the paper. The research was partially financed by USDA Grant S-1043: Economic Impacts of International Trade and Government Domestic Policies on Southern Agriculture, and USDA Farmers Market Promotion Program Grant.

\section{References}

[1] U.S. Department of Agriculture, Economic Research Service (ERS), Vegetables and Specialties Situation and Outlook Report, Washington, DC, USA, 2000.
[2] R. L. Cook, "The U.S. fresh produce industry: an industry in transition," in Postharvest Technology of Horticultural Crops, A. A. Kader, Ed., vol. 3311, chapter 2, pp. 27-117, University of California Division of Agriculture and Natural Resources, 2001.

[3] U.S. Bureau of the Census, Population Statistics, Washington, DC, USA, 2010.

[4] Z. You, C. L. Huang, and J. E. Epperson, "Demand elasticities for fresh vegetables in the United States," Journal of International Food and Agribusiness Marketing, vol. 9, no. 2, pp. 57-71, 1997.

[5] Z. You, J. E. Epperson, and C. L. Huang, "Consumer demand for fresh fruits and vegetables in the United States (19601993)," UGA Cooperative Extension RB 431, 2011.

[6] S. R. Henneberry, K. Piewthongngam, and H. Qiang, "Consumer food safety concerns and fresh produce consumption," Journal of Agricultural and Resource Economics, vol. 24, no. 1, pp. 98-113, 1999.

[7] A. Deaton and J. Muellbauer, "An almost ideal demand system," American Economic Review, vol. 70, no. 3, pp. 312326, 1980.

[8] F. M. Sacks and M. Katan, "Randomized clinical trials on the effects of dietary fat and carbohydrate on plasma lipoproteins and cardiovascular disease," American Journal of Medicine, vol. 113, supplement 9, pp. 13S-24S, 2002.

[9] K. Oh, F. B. Hu, J. E. Manson, M. J. Stampfer, and W. C. Willett, "Dietary fat intake and risk of coronary heart disease in women: 20 Years of follow-up of the nurses' health study," 
American Journal of Epidemiology, vol. 161, no. 7, pp. 672-679, 2005.

[10] L. A. Bazzano, J. He, L. G. Ogden, C. M. Loria, and P. K. Whelton, "Dietary fiber intake and reduced risk of coronary heart disease in US men and women: the National Health and Nutrition Examination Survey I Epidemiologic Followup study," Archives of Internal Medicine, vol. 163, no. 16, pp. 1897-1904, 2003.

[11] O. Capps and J. D. Schmitz, "A recognition of health and nutrition factors in food demand analysis," Western Journal of Agricultural Economics, vol. 16, no. 1, pp. 21-35, 1991.

[12] U.S. Depaprtment of Agriculture, Farmers Market Growth: 1994-2011. National Famers Market Directory, Agricultural Marketing Service, U.S. Department of Agriculture, 2011.

[13] H. R. Varian, Microeconomic Analysis, W.W. Norton \& Company, 3rd edition, 1992.

[14] J. M. Alston and J. A. Chalfant, "The silence of the lambdas: a test of the almost ideal and rotterdam models," American Journal of Agricultural Economics, vol. 75, pp. 304-313, 1993.

[15] A. P. Barten, "Consumer demand functions under conditions of almost additive preferences," Econometrica, vol. 32, pp. 138, 1964.

[16] H. Theil, "The information approach to demand analysis," Econometrica, vol. 33, pp. 67-87, 1965.

[17] J. M. Alston and J. A. Chalfant, "Accounting for changes in demand," in Proceedings of the Australian Agricultural Economics Society Annual Conference, 1991.

[18] J. M. Alston and J. A. Chalfant, "Can we take the con out of meat demand studies?" Journal of Agricultural and Resource Economics, vol. 16, pp. 36-48, 1991.

[19] G. W. Brester and M. K. Wohlgenant, "Estimating interrelated demands for meats using new measures for ground and table cut beef," American Journal of Agricultural Economics, vol. 73, pp. 1182-1194, 1991.

[20] E. W. Goddard, "Advertising butter and margarine in Canada," in Market Demand for Dairy Products, S. R. Johnson, D. P. Stonehouse, and Z. A. Hassan, Eds., p. 259, Iowa State University Press, 1992.

[21] L. Phlips, Applied Consumption Analysis, North Holland, Amsterdam, The Netherlands, 1974.

[22] D. L. Edgerton, "Weak separability and the estimation of elasticities in multistage demand systems," American Journal of Agricultural Economics, vol. 79, no. 1, pp. 62-79, 1997.

[23] A. McGuirk, P. Driscoll, J. Alwang, and H. Huang, "System misspecification testing and structural change in the demand for meats," Journal of Agricultural and Resource Economics, vol. 20, no. 1, pp. 1-21, 1995.

[24] J. S. Eales and L. J. Unnevehr, "Demand for beef and chicken products: separability and structural change," American Journal of Agricultural Economics, vol. 70, no. 3, pp. 521-532, 1988. 


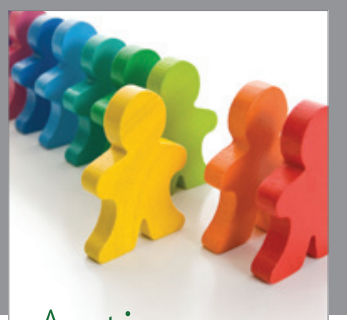

Autism

Research and Treatment
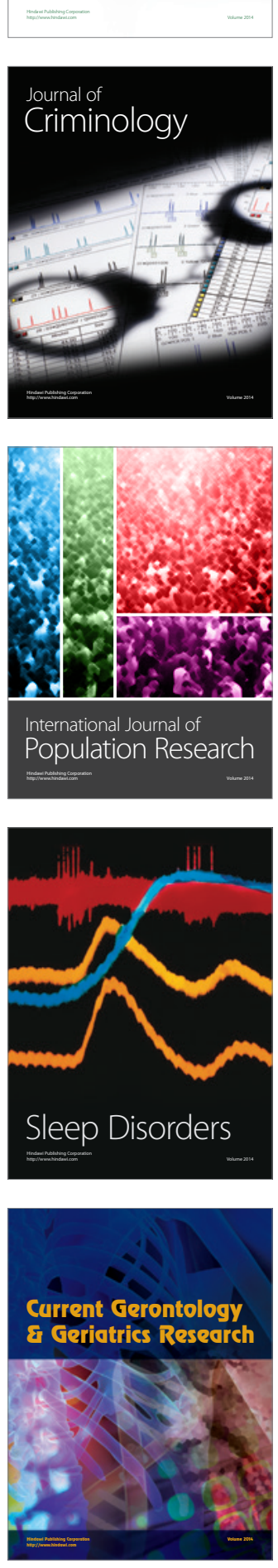
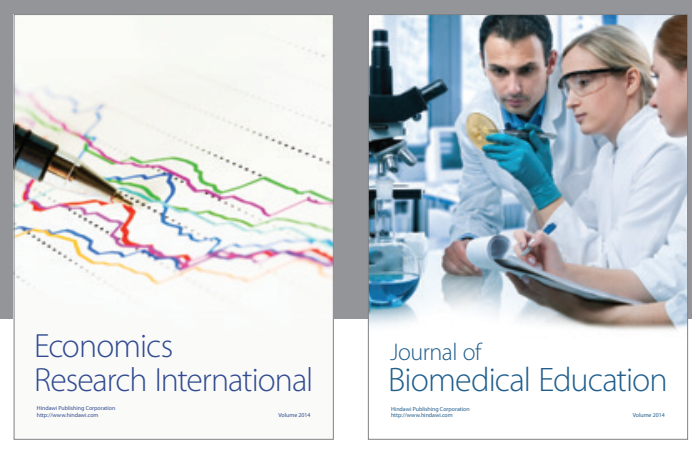

Journal of

Biomedical Education

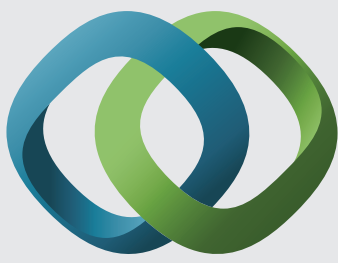

\section{Hindawi}

Submit your manuscripts at

http://www.hindawi.com
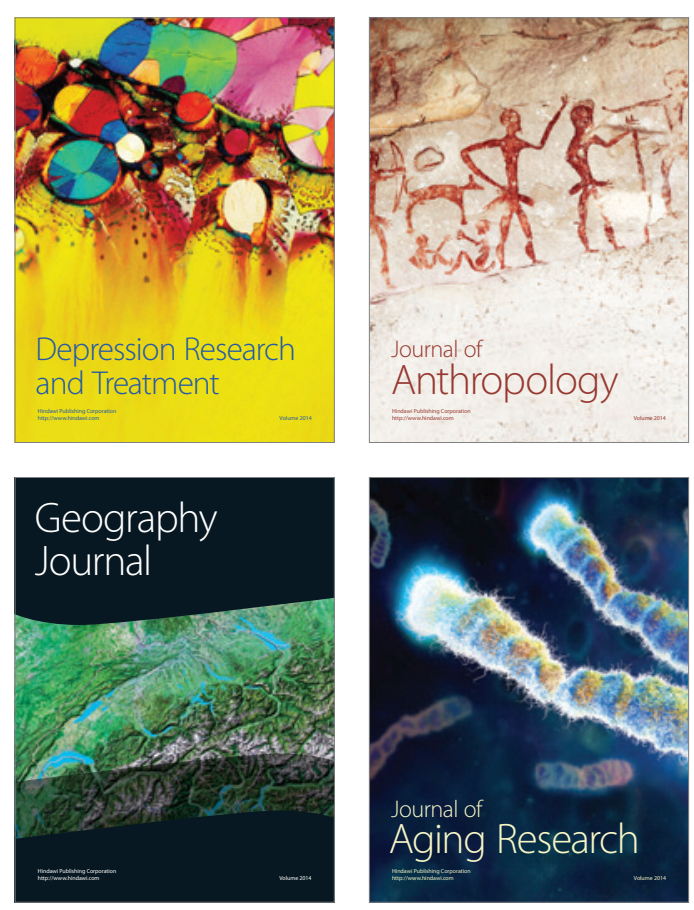

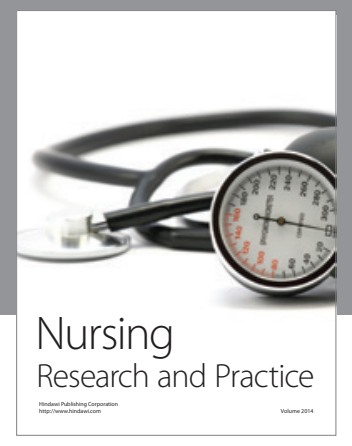

Nursing

Research and Practice

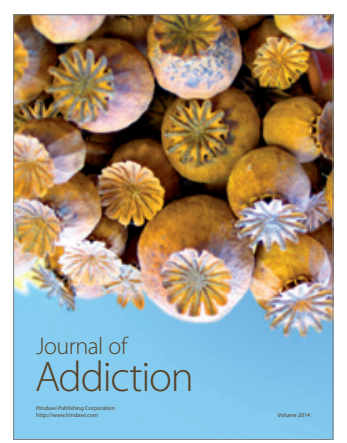

Child Development

Research

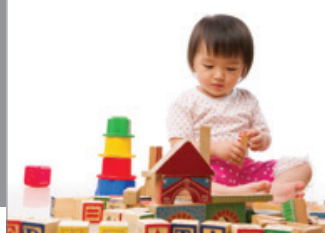

迥
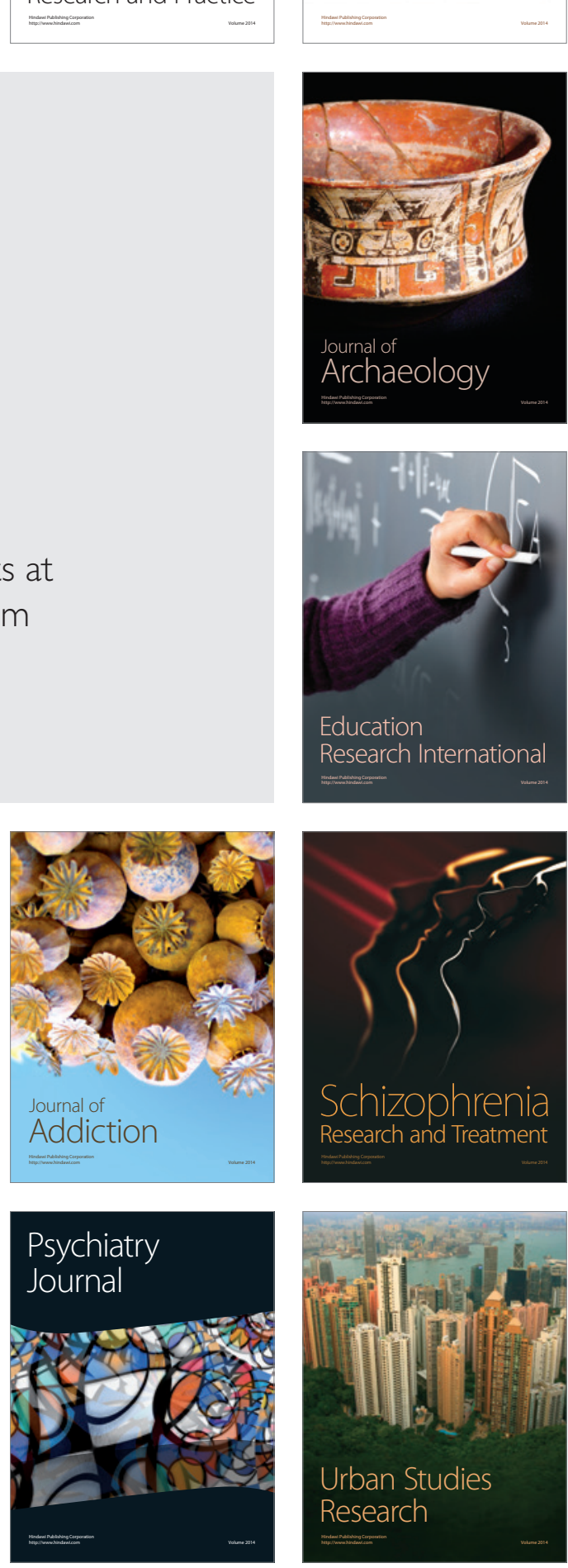